JASEM ISSN 1119-8362

All rights reserved
Full-text Available Online at www.bioline.org.br/ja
J. Appl. Sci. Environ. Manage. June, 2007

Vol. 11 (2) 215 - 221

\title{
Extent and Distribution of Groundwater Resources in Parts of Anambra State, Southeastern, Nigeria
}

\author{
*NFOR, B N; OLOBANIYI, S B; OGALA, J E \\ Department of Geology, Delta State University, P.M.B. 01 Abraka, Delta State, Nigeria
}

\begin{abstract}
The extent and distribution of groundwater resources in parts of Anambra State, Nigeria has been investigated. The results show that the study area is directly underlain by four different geological formations including, Alluvial Plain Sands, Ogwashi-Asaba Formation, Ameki/Nanka Sands and Imo Shale, with varying water storage and yielding capacities. Borehole depths within the Alluvial Plain Sands are shallow $(5-30 \mathrm{~m})$ yet the sands are excellent aquifers with high yields (3-5 litres/sec) especially along the Anambra West - Onitsha Ogbaru L.G.A. axis. Elsewhere the yield is low (about 0.5 litres $/ \mathrm{sec}$ ) and may dry up at peak dry season periods. The Ogwashi-Asaba Formation occurs in a north-southerly trend and underlies Ekwusigo, Nnewi North and South and Ihiala Local Government Areas. This formation consists of multiple aquifers and a depth to water table ranging from 50 to $110 \mathrm{~m}$. Within it, transmissivity values of 37.54 to $95.5 \mathrm{~m}^{2} /$ day and a yield of up to 5 litres $/ \mathrm{sec}$ were recorded. The Ameki/Nanka Sands is a prolific water producer and underlies Aguata, Anaocha, Njikoka, Dunukofia, Oyi and Anambra East Local Government Areas. Four aquifer horizons were identified within this formation, designated; shallow, upper, middle and deep aquifers. The most exploited are the upper and middle aquifers, while the least, but most prolific is the deep aquifer with an average yield of 5 litres/sec. Imo Shale, because of its sedimentological nature is a poor aquifer. The gravelly intercalations within this formation are usually too thin to sustain continuous water pumping. This study indicates that the extent and distribution of groundwater within the study area is controlled predominantly by lithology and other secondary factors including topography and nearness to source of recharge. @JASEM
\end{abstract}

The Anambra State lies within longitudes $06^{0} 31^{\prime}$ and $07^{0} 03^{\prime} \mathrm{E}$ and latitudes $05^{\circ} 45^{\prime}$ and $06^{\circ} 46^{\prime} \mathrm{N}$. (Fig. 1) and covers an estimated surface area of $7200 \mathrm{~km}^{2}$. The area is underlain by Cretaceous to Recent sedimentary formations of the Anambra Basin that are of varying aquifer potentials. Several studies including those of Ezeigbo, 1987; Ezeigbo and Ozoko, 1989; Egboka, 1990 and 1993; Ezenwa, 1996; Onwuemesi and Olaniyan, 1996 and Ofomah and Ezeigbo, 1997 have reported aspects of the hydrogeology and quality status of groundwater within the State. These reports indicated that groundwater within the State consists predominantly of low concentrations of major ions and microbial content and consequently suitable for domestic purposes. Despite these investigations, very little information yet exists on the nature of aquifer distribution and their properties, within the formations that underlie the study area.

Between the years 1998 and 2001 a systematic borehole drilling across 18 Local Government Area of Anambra State was embarked upon. A total of forty-five (45) boreholes were drilled and investigated to delineate the constituent aquifers and assess their properties in the various locations. These form the basis for the evaluation of the extent and distribution of groundwater within Anambra State. It is hoped that information presented in this paper would be a useful guide for groundwater exploration within the study area.
Geologic Units within the Anambra Basin: The Basin is dominantly filled with clastic sediments constituting several distinct lithostratigraphic units ranging from Upper Campanian to Recent in age. The lithostratigraphic units have a thickness of up to 2500m (Reyment, 1965) and consist of Nkporo Shale, Mamu Formation, Ajali Sandstone, Nsukka Formation, Imo Shale, Ameki Formation, Nanka Sands, Ogwashi-Asaba Formation, Benin Formation and the Alluvial plain Sands. The source of the sediments into the basin is principally from the Cameroon massif and the Abakaliki synclinorium (Nfor, 2003). The general stratigraphy of the Anambra-Abakaliki basins is presented in Table 1.

\section{METHODOLOGY}

Pre-drilling geophysical surveys were conducted at each site with an SAS 300B ABEM Terrameter and its accessories, using the Schlumberger configuration. The main objective of the surveys was to determine the depths to potable water. Probe depth $((\mathrm{AB} / 2)$ was $600 \mathrm{~m}$. Hydrogeological/geological surveys were undertaken on existing boreholes with the aim of knowing the static water level, drilled depths, casing and screen positions etc. During drilling, return cuttings were collected at 1meter-drilled depth interval and used to study grain-size, colour and associated interstitial materials useful in the determination of screen slot and gravel pack specification. After drilling to target depth, each borehole was logged for electromagnetic properties including spontaneous potential and resistivity (16" short normal and 64" long normal) using ABEM 
Terrameter. In the absence of observation wells, all measurements during pumping tests were done on the pumping wells. An integration of the results of predrilling geophysical survey, hydrogeological/geological survey, drill cuttings, granulometric analysis, down-hole logging, drill time and pumping test/analysis for each borehole, provided the basis for establishing the extent and distribution of the groundwater resources in Anambra State.

Table 1: The Stratigraphy of the Anambra-Abakaliki Basins (Reyment, 1965)

\begin{tabular}{ll}
\hline Age & Stratigraphic Unit \\
Eocene & Ameki Group (Including Nanka Sands, Nsugbe Formation) \\
Palaeocene & Imo Shale \\
Maestrichtian & Nsukka Formation, Ajali Sandstone, Mamu Formation \\
Campanian & $\begin{array}{l}\text { Nkporo Group (including Nkporo Shale, Oweli Sandstone, Enugu Shale, } \\
\text { Afikpo Sandstone, Otobi Sandstone) }\end{array}$ \\
Santonian & NON-DEPOSITION \\
Coniacian & Awgu Group (including Awgu Shale, Agbani Sandstone) \\
Turonian & Ezeaku Formation (including, Amaseri Sandstone) \\
Cenomanian & Odukpani Formation \\
Albian & Asu River Group \\
Precambrian & Basement Complex
\end{tabular}

\section{RESULTS AND DISCUSSION}

Vertical Electrical Sounding (VES): Representative VES curves from three locations are presented (Fig. 2). These include, Oroma Etiti within the Alluvial plain of the River Niger; Obeledu, within the Ameki/Nanka Sands and Nteje, within the Imo Shale/Ajali Sands. In Oroma Etiti, the VES curve type is $\mathrm{KH}$ and of the nature $\mathrm{S}_{1}<\mathrm{S}_{2}<\mathrm{S}_{3}$. Its geoelectric section delineates three surfaces of geological layers including an overburden, sandstone aquifers and sandstone/fractured shale, with thicknesses of $5 \mathrm{~m}, 105 \mathrm{~m}$ and $110 \mathrm{~m}$ respectively and corresponding resistivities of 150, 600 and $55 \mathrm{ohm}-$ $\mathrm{m}$. In Nteje, the VES curve type is $\mathrm{KH}$, with geoelectric layers are homogenous with isotropic beds. The curve depicts five layers; top layer, shale/clay, ferruginized sandstone, clay/shale and a saturated aquiferous sand layer. Their thicknesses are $2 \mathrm{~m}, 17 \mathrm{~m}, 87 \mathrm{~m}, 168 \mathrm{~m}$ and $187 \mathrm{~m}$ respectively, with corresponding resistivities are 300, 850, 1000, 900, and 630 ohm-m. In Obeledu, a HAK-type curve was obtained. The geoelectric section indicates a sequence of lithologies including a top sandy layer, clay, claysandstone intercalations and aquiferous sand. The thickness and average resistivity values of the top four litholofacies are $0.5 \mathrm{~m}$ and $760 \mathrm{hm}-\mathrm{m}, 1.1 \mathrm{~m}$ and 65 ohm-m, $12.8 \mathrm{~m}$ and 1079 ohm-m, 105.1m and $10927 \mathrm{ohm}-\mathrm{m}$ respectively. The aquiferous sand layer is of infinite thickness with an average resistivity of 485 ohm-m.

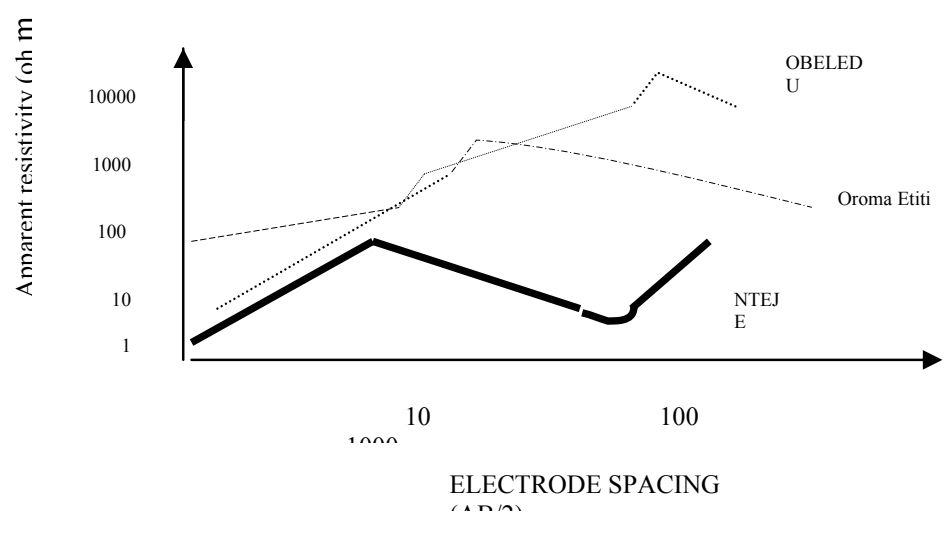

Fig. 2: Vertical electrical sounding (VES) for some boreholes in Anambra State 
(b) Lithology: The spatial distribution of lithologic outcrops and formations within the study area is presented in figure 3 with the downhole lithostratigraphic variations within the various formations are shown in figure 4.

Straddling the River Niger is a narrow N-S trending belt of Alluvial plain Sands deposited by the river at an average topographic height of $25 \mathrm{~m}$ above sea level. The vertical lithologic variation within this unit is seen in figure $2 b$ and consists predominantly of $a$ fining upward sequence of sand and silt. In the northern portion of the study area, the outcropping formation consists predominantly of Imo Shale. This formation extends southeasterly within a narrow band at an average elevation of $45 \mathrm{~m}$ above sea level and defines the eastern boundary of Anambra State. Lithologically, this formation consists of a lateritic cover, underlain by a thick sequence of shale (Fig.2f). Sandwiched between the Alluvial plain Sands and the Imo Shale, around the central and southern portions of the study area, are two formations, the OgwashiAsaba Formation and the Ameki/Nanka Sands. The lithostratigraphic sequence within the Ogwashi-Asaba Formation is depicted by figure 2c. The OgwashiAsaba Formation underlains towns extending from
Oba, Oraifite, Nnewi to parts of Ihiala etc. whose average elevation is $60 \mathrm{~m}$ abov sea level. It consists of a top layer of black to brownish humus and laterite, underlain by horizons of sands, clays, gravels and cobbles with intercalations of brown to black lignitic coal. The Ameki/Nanka Sands (Fig. 2e) consists of a top lateritic sandy layer underlain by a near monotonous sandy horizon, with occasional intercalations of thin clay and gravelly beds. Elevations here range from $70 \mathrm{~m}$ above sea level in the Awka-Amansea axis, to about $280-350 \mathrm{~m}$ above sea level in the Obeledu-Ikenga-Isoufia Aguluezechukwu axis.

Aquifer Delineation and Characteristics: The aquiferous formations within Anambra State include the Alluvial Plain Sands, the Ogwashi-Asaba Formation and the Ameki/Nanka Sands. These formations were encountered in different towns with Anambra State. Results of borehole drilled-depths, water levels, static water levels and aquifer intervals of some of the boreholes are presented in Table 2 .

Within the Alluvial plain sediments (encountered within Anambra West and Ogbaru LGAs), boreholedrilled depths are shallow and vary from 32 to $120 \mathrm{~m}$.

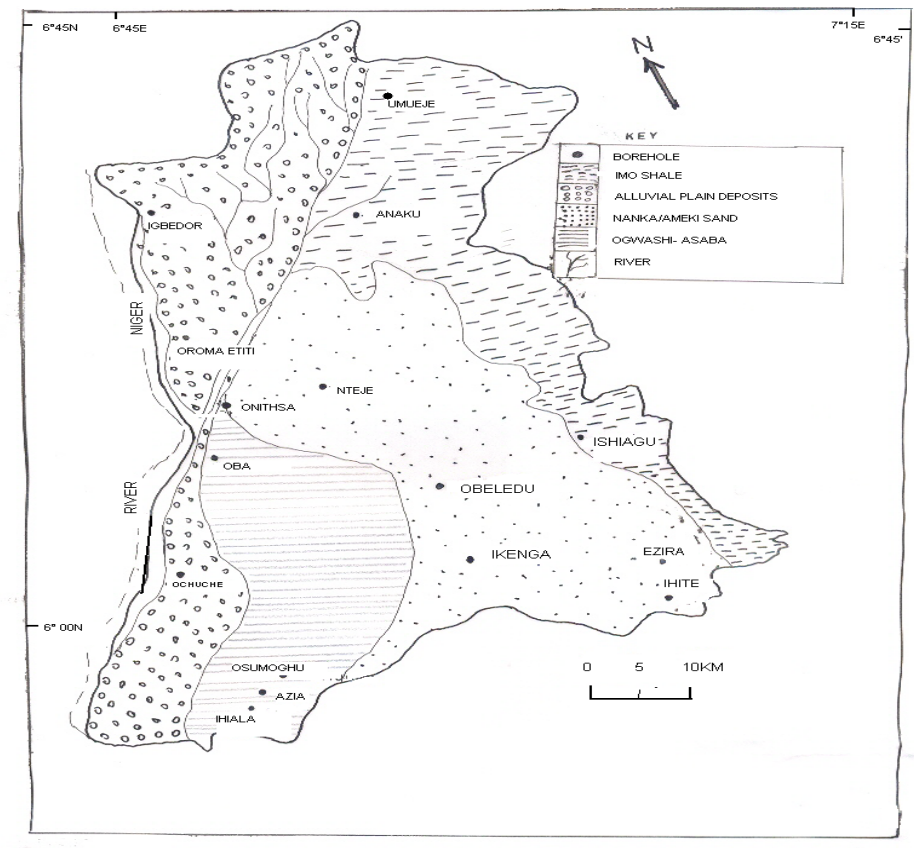

Fig. 3: spatial distribution of geologic units across Anambra state 


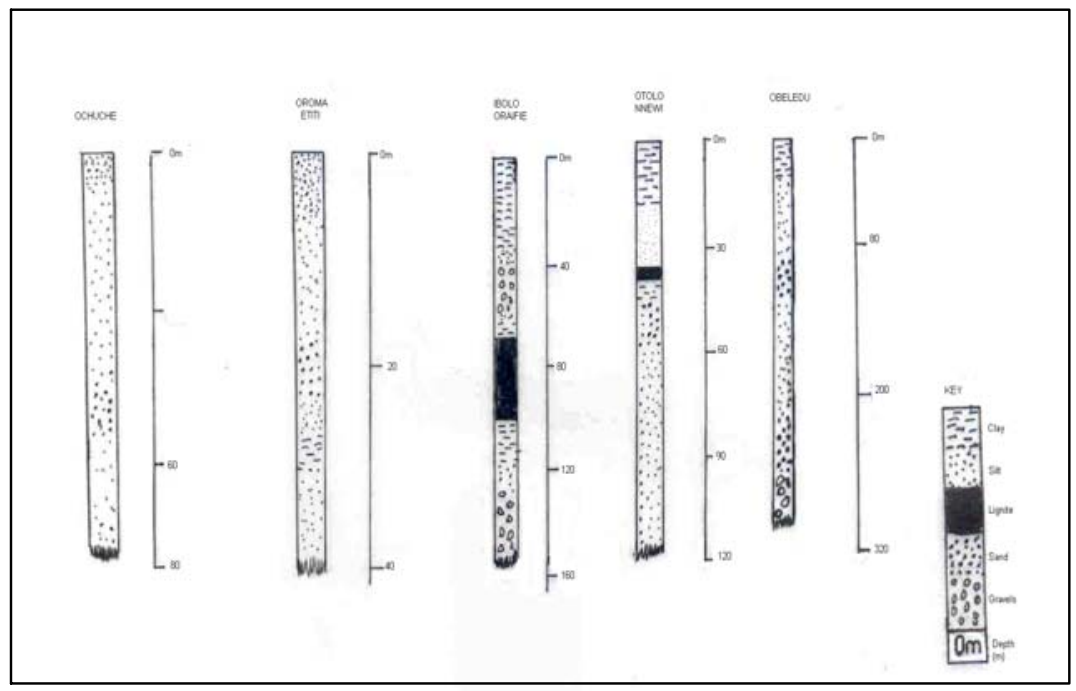

Fig. 4. Lithologic Logs of Some Boreholes in Anambra State

A very productive multi-aquiferous system at depths of $10-20 \mathrm{~m}$ and $25-40 \mathrm{~m}$ were identified. Water levels and static water levels (SWLs) within this geologic unit vary from $5.5-30 \mathrm{~m}$ and $10-65 \mathrm{~m}$ in the two Local Government Areas respectively. At Oroma Etiti, in Anambra West Local Government Area, results of borehole tests indicate a transmissivity of $210.3 \mathrm{~m}^{2} /$ day, critical discharge of $13.6 \mathrm{~m}^{3} / \mathrm{h}$ and a draw down of $2.2 \mathrm{~m}$ (Table 3.and Fig. 5.), thus reflecting the aquiferous nature of the alluvial deposits.

The Ogwashi-Asaba Formation underlies Ekwusigo, Nnewi North and South, and Ihiala Local Government Areas. Boreholes drilled within this axis have drilled-depths ranging from 125 to $250 \mathrm{~m}$. Within this formation, three multiple aquifers were identified at depths of $30-50 \mathrm{~m}, 70-90 \mathrm{~m}$ and $140-$ $165 \mathrm{~m}$ with corresponding static water levels of $40 \mathrm{~m}$, $69 \mathrm{~m}$ and $120 \mathrm{~m}$ respectively. At Otolo-Nnewi, a transmisivity of $95.5 \mathrm{~m}^{2} /$ day and a yield of 5litres/ sec. were recorded. At Ibolo-Oraifite borehole yield tests within this formation gave transmisivity of $37.54 \mathrm{~m}^{2} /$ day, a critical discharge of $12.3 \mathrm{~m}^{3} / \mathrm{h}$ and a draw down of $1.07 \mathrm{~m}$. Boreholes within the Ameki/Nanka Sands drilled within Aguata, Anaocha,
Njikoka, Dunukofia, Oyi and Anambra East Local Government Areas, have drilled depths ranging from $75 \mathrm{~m}$ to $350 \mathrm{~m}$. This formation is prolific in water production, having four aquifer horizons, and identified as; shallow, upper, lower and deep aquifers. Of these, the most exploited are the Upper and Lower aquifers, while the most prolific is the Deep aquifer with an average of 5 litres/sec.. Water levels within the formation vary from 6 to $10 \mathrm{~m}$ and the static water levels could be as deep as $200 \mathrm{~m}$ in some places. Nevertheless, within Aguata Local Government Area (spot height of Anambra State) especially in Ikenga and Aguluezechukwu, boreholes were abortive even at $350 \mathrm{~m}$ and $300 \mathrm{~m}$ depths respectively. The Imo Shale, because of its sedimentological nature constitutes a poor aquifer. This formation underlies parts of Orumba South, parts of Awka North and South and Ayamelum Local Government Areas. Borehole drilled-depths within this formation vary from $38 \mathrm{~m}$ in Awka area to $220 \mathrm{~m}$ in Oyi Local Government Area. The water level is as shallow as 1.7 in Ayamelum but the quantity of water is generally low and often does not sustain continuous pumping for periods longer than 2 minutes even with a low capacity ( $0.5 \mathrm{~h} . \mathrm{p})$ pumps. 
Table 2. Summarized data of borehole drilled depths, water table, static water level/aquifer intervals (Compiled by Nfor, B.N., 1999)

\begin{tabular}{|c|c|c|c|c|c|}
\hline $\begin{array}{l}\text { Local } \\
\text { Government Area }\end{array}$ & Town & $\begin{array}{l}\text { Drilled } \\
\text { Depth } \\
(\mathrm{m})\end{array}$ & $\begin{array}{l}\text { Water } \\
\text { Table } \\
(\mathrm{m})\end{array}$ & $\begin{array}{l}\text { Static } \\
\text { Water } \\
\text { Level m) }\end{array}$ & $\begin{array}{l}\text { Aquifer/screen } \\
\text { (m) }\end{array}$ \\
\hline \multirow[t]{2}{*}{ Orumba South } & Ihite & 200 & 60 & 80 & $86-92 ; 95-101$ \\
\hline & Ezira & 200 & 63 & 80 & $72-75 ; 106-112$ \\
\hline \multirow[t]{2}{*}{ Orumba North } & Awa & 110 & 40 & 45 & $58-67 ; 75-78$ \\
\hline & Ufuma & 150 & 20 & 25 & $34-37 ; 48-57$ \\
\hline \multirow[t]{2}{*}{ Aguata } & Ikenga & 350 & - & - & - \\
\hline & Aguluezechukwu & 300 & - & - & - \\
\hline Nnewi South & Osumenyi & 250 & 50 & 69 & $145-148 ; 163-166$ \\
\hline \multirow[t]{2}{*}{ Nnewi North } & Obiofia & 250 & 110 & 120 & $178-200$ \\
\hline & Otolo-Nnewi & 125 & 40 & 70 & $50-55 ; 92-104$ \\
\hline Awka South & Amanuke & 250 & 16 & - & $20-23 ; 24-30$ \\
\hline \multirow[t]{2}{*}{ Awka North } & Nnodu-Okpuno & 168 & 35 & 40 & $48-60$ \\
\hline & Ishiagu & 250 & 6 & - & $6-65 . ; 7-13$ \\
\hline \multirow[t]{2}{*}{ Ekwusigo } & Ibolo-Oraifite & 168 & 30 & 40 & $\begin{array}{l}42-60 ; 130-135 ; 152-165 \\
75-100 ; 140-160\end{array}$ \\
\hline & Awor-Oraifite & 168 & 70 & 86 & \\
\hline \multirow[t]{2}{*}{ Njikoka } & Enugwu-Ukwu & 170 & 36 & 55 & $48-55 ; 78-102$ \\
\hline & Abba & 150 & 60 & 90 & $100-118 ; 126-148$ \\
\hline \multirow[t]{2}{*}{ Dunukofia } & Ukpo & 147 & 40 & 70 & $\begin{array}{l}38-40 ; 56-82 ; 95-120 \\
38-60 ; 66-120\end{array}$ \\
\hline & Umudioka & 120 & 30 & 65 & $48-57$ \\
\hline \multirow[t]{2}{*}{ Ogbaru } & Ochuche & 75 & 6 & 10 & $40-49$ \\
\hline & Ugwuaniocha & 75 & 6 & 10 & $40-49$ \\
\hline \multirow[t]{2}{*}{ Oyi } & Nteje & 220 & 40 & $\begin{array}{l}45 \\
\text { Artesian }\end{array}$ & $30-50 ; 72-82 ; 182-216$ \\
\hline & Awkuzu & 220 & 50 & 50 & $38-60 ; 66-120$ \\
\hline \multirow[t]{2}{*}{ Ihiala } & Azia & 150 & 90 & 90 & $86-95 ; 100-132$ \\
\hline & Osumoghu & 220 & 110 & 115 & $110-125 ; 128-146 ; 150-178$ \\
\hline \multirow[t]{5}{*}{ Anambra West } & Nzam & 40 & 5.5 & 10 & $34-37$ \\
\hline & Umuenwelum & 42 & 5.5 & 10 & $31-34$ \\
\hline & Oroma-Etiti & 40 & 5.5 & 10 & $29-32$ \\
\hline & Igbedor & 42 & 5.5 & 10 & $36-39$ \\
\hline & Igbokenyi & 37 & 5.5 & 10 & $25-28$ \\
\hline \multirow[t]{5}{*}{ Ayamelum } & Igbaku & 38 & 2.7 & - & $31-34$ \\
\hline & Omasi-Agu & 40 & 1.7 & - & $15-19 ; 28-31$ \\
\hline & Umuerum & 50 & 2.1 & - & $13-16 ; 32-35$ \\
\hline & Umueje & 60 & - & - & $18-21 ; 36-39$ \\
\hline & Anaku & 46 & 3 & - & $21-30$ \\
\hline \multirow[t]{2}{*}{ Anaocha } & Akwaeze & 303 & 168 & 200 & $265-279$ \\
\hline & Obeledu & 303 & 120 & 150 & $260-282$ \\
\hline \multirow[t]{2}{*}{ Idemili North } & Eziowele & 225 & 60 & 91 & $50-60 ; 72-108$ \\
\hline & Uke & 220 & 100 & 127 & $176-194$ \\
\hline Anambra East & Nsugbe & 125 & 31.5 & 68 & $27-37 ; 65-112 ; 117-120$ \\
\hline
\end{tabular}

Table 3: Aquifer Parameters Of Some Boreholes In Anambra State (Compiled by Nfor, B.N. 1999)

\begin{tabular}{lllll}
\hline Town & $\begin{array}{l}\text { Transmisivity } \\
\left(\mathrm{m}^{2} / \text { day }\right)\end{array}$ & $\begin{array}{l}\text { Critical } \\
\left(\mathrm{m}^{3} / \mathrm{h}\right)\end{array}$ & Discharge & $\begin{array}{l}\text { Draw } \\
(\mathrm{m})\end{array}$ \\
Ibolo-Oraifite & 37.54 & 12.3 & 1.07 & \\
Oroma Etiti & 210.3 & 13.6 & 2.2 & \\
Otolo Nnewi & 95.5 & $\overline{8} .15$ & $\overline{8} .21$ \\
Ihite & 3.1 & & \\
\hline
\end{tabular}




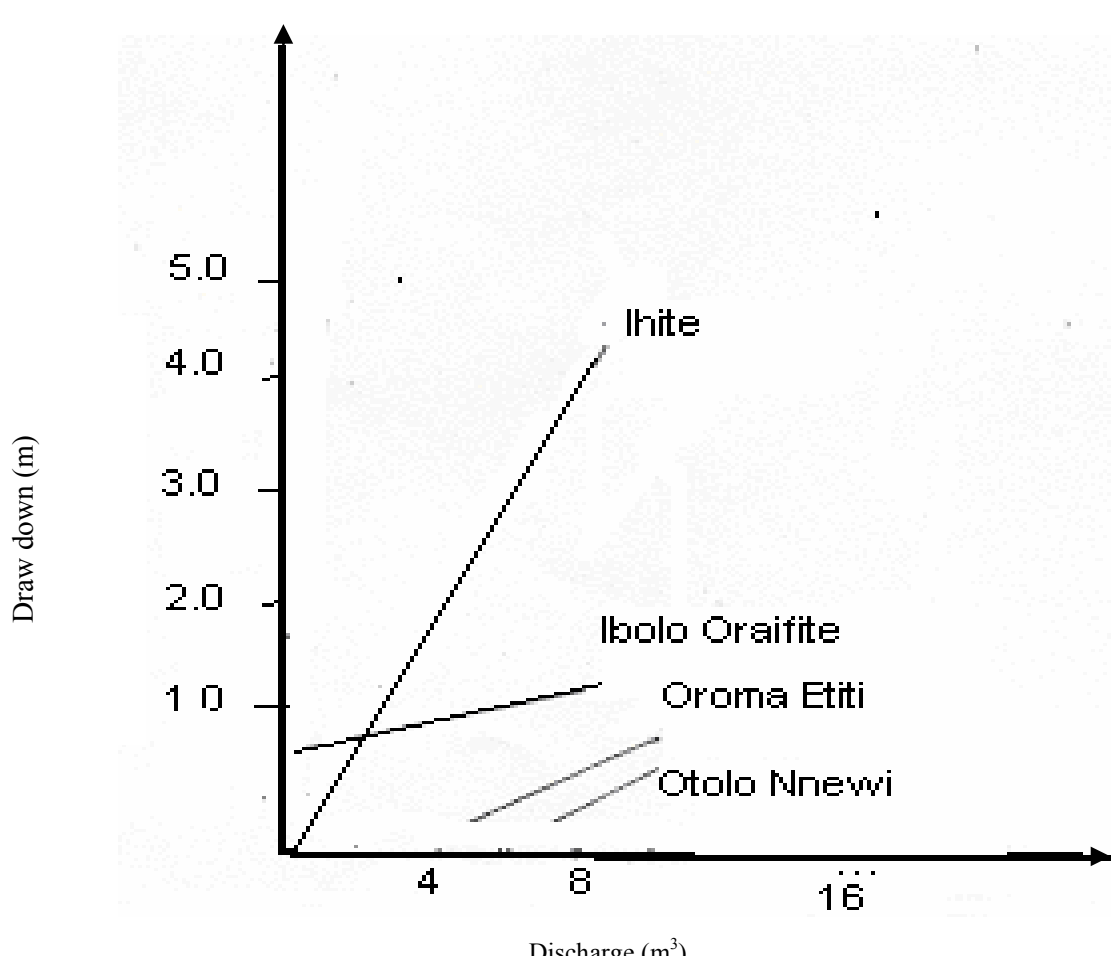

Fig. 5: discharge - draw down curves for some boreholes in the study area

The occurrence of groundwater, depth to water table, depth to static water level, depth to screen/aquifer positions in the studied water boreholes of Anambra State have been shown to be fairly consistent within the same lithologic units, but varies only with differences in elevation. Along the banks of the Niger and the Anambra Rivers, drill depths, water table, static water level and screen/aquifer positions are quite shallow. The towns located in this area, such as Ogwuaniocha, Onitsha, and Igbedor, have an average elevation of $25 \mathrm{~m}$ above sea level. The main problem militating against water quality here is the high iron content which alters the colour of the water to reddish brown on exposure to free air and hence undesirable. The shallow nature of the aquifer implies that water was being tapped from the deep lateritic soil, from where iron is being readily contributed to the groundwater.

In areas underlain by Imo Shale such as Ayamelum Local Government Area, which are averagely $45 \mathrm{~m}$ above sea level it is expected that the drill depths and water levels etc. would be higher sympathetically with the elevation difference of about $20 \mathrm{~m}$ (compared to $20 \mathrm{~m}$ elevation in Alluvial plain areas). Contrary to this expectation, a small amount of water is available within the gravel intercalations of the Imo Shale between $20-60 \mathrm{~m}$, which is usually too small to sustain pumping. Within this area, sustainable water production is only achieved by drilling beyond the Imo Shale (over 500m) into the underlying aquiferous Ajali Sandstone. This shows the over-riding influence of lithology on groundwater distribution in the state.

Within the Ogwashi-Asaba Formation, the lignitic coal is a critical factor in the citing of boreholes. This is because a loss in circulation is often experienced during drilling within this unit. This could necessitate drill depths of up to $250 \mathrm{~m}$ to ensure stable static water level in the drier periods. Local modifications exist in riverine areas nearer to the distributaries of the River Niger where static water levels could be as shallow as $30 \mathrm{~m}$.

In the central and southern parts of the State, where Ameki/Nanka Sands outcrop, aquifer characteristics show much disparity; water levels range from 6-35m in Awka to between 20 to $168 \mathrm{~m}$ in Anaocha Local Government Area, with static water levels ranging between of $20-175 \mathrm{~m}$. The influence of elevation can 
be seen around Anaocha, Onitsha and Anambra West Local Government Areas. In areas such as Anambra West Local Government Area, with an average elevation of $25 \mathrm{~m}$ above sea level, depth to the water table is averagely $6 \mathrm{~m}$. On the other hand, areas with high topographic elevations such as Anaocha (about $300 \mathrm{~m}$ above sea level) and Oyi Local Government Area ( about $70 \mathrm{~m}$ above sea level) have water depths of $120-160 \mathrm{~m}$ and 70-180m respectively. Also, since the Ameki/Nanka Sand dips gently away from a water divide that runs from the north to the south of the area, (Reyment, 1965), groundwater consequently flows southwesterly and easterly away from the water divide. Such flow pattern could contribute to the low storage capacity sometimes recorded within the Formation.

Acknowledgement: The author is grateful to the Mr. Bawa Aliyu of Brossette (Nig.) Ltd and Engr. Edwin Enweagbara of Eauxwell (Nig.) Ltd; who provided the author the opportunity to serve in the companies in the capacity of well site geologist and Project Manager during the PTF (Special) sponsored Rural Water Supply Project in Anambra State. Mr. Donatus Iberi of KINGS PAINTS provided financial support. Our gratitude also go to Dr. A U. Oteri, Mr.S.O. Ezenwa, Mr Leo Ezenwagi, Dr. A.G. Onwuemesi and Mr. Goodluck Oboh who carried out the Geophysical survey.

\section{REFERENCES}

Egboka, BCE, (1993). The Raging War. God's Time Printing \& Publishing, Awka. P223

Egboka, BCE., Nwankor, GI and Orajaka, IP (1990). Investigations of Paleo and Neotectonics in Gully Erosion-prone Areas of Southeastern Nigeria. Natural Hazards. Vol. 3, pp. 219-231.
Ezeigbo, HI (1987). Quality of water resources in Anambra State, Nigeria. Journal of Mining and Geology. No. 23, Vol. 1 and 2, pp. 97-103.

Ezeigbo, HI; Ozoko, DC, (1989). An Evaluation of the Water Resources of Nsukka and environs, Anambra State, Nigeria. Water Resources Journal of Nigeria Association of Hydrogeologists. Vol. No. 2. pp. 20-25.

Ezenwa, SO (1996). The Relationship between Total Dissolved Solids (TDS) and Total Dissolved Iron (TDI) in aquifers of Southern Anambra Basin. Water Resources Journal of Nigeria Association of Hydrogeologists. Vol. 7 No. 1. pp31-42.

Ofomah, JC; Ezeigbo, HI (1997). Hydrogeological Evaluation of the Anambra River Basin, Southeastern Nigeria. Water Resources Journal of Nigeria Association of Hydrogeologists. Vol. 8. Nos. 1and 2. pp 18-26

Onwuemesi, AG; Olaniyan, IO (1996). Hydrogeological Investigation of parts of Anambra State, Nigeria. Water Resources Journal of Nigeria Association of Hydrogeologists. Vol. 8. Nos. 1and 2. pp 56-61.

Nfor, BN, (2003). Sedimentary Facies and the Diagnostic Characteristics for the CampanianEocene Anambra Basin; Unpublished PhD thesis submitted to the Department of Geological Sciences, Nnamdi Azikiwe University, Awka. 236P.

Reyment, RA, (1965). Aspects of the Geology of Nigeria. University of Ibadan Press. 133P. 